\title{
Genomic heterogeneity meets cellular energetics: crosstalk between the mitochondria and the cell cycle
}

\author{
Erica L. Herrera, Seham Z. Azzam, Madison C. Berger, Laura A. Diaz-Martinez \\ Department of Biological Sciences, The University of Texas at El Paso, El Paso, TX 79968, USA.
}

Correspondence to: Dr. Laura A. Diaz-Martinez, Department of Biological Sciences, The University of Texas at El Paso, 500 West University Avenue, El Paso, TX 79968, USA. E-mail: ladiazmartinez@utep.edu

\begin{abstract}
How to cite this article: Herrera EL, Azzam SZ, Berger MC, Diaz-Martinez LA. Genomic heterogeneity meets cellular energetics: crosstalk between the mitochondria and the cell cycle. J Cancer Metastasis Treat 2018;4:42.

http://dx.doi.org/10.20517/2394-4722.2018.35
\end{abstract}

Received: 3 Jun 2018 First Decision: 5 Jul 2018 Revised: 12 Jul 2018 Accepted: 19 Jul 2018 Published: 6 Aug 2018

Science Editor: Yi-Hong Zhou Copy Editor: Jun-Yao Li Production Editor: Cai-Hong Wang

\begin{abstract}
Changes in cellular energetics and genomic instability are two characteristics of cancers that have been studied independently. Evidence of cross-talk between mitochondria function and nuclear function has started to emerge, suggesting that these pathways can influence one another. Here we review recent evidence that links the mitochondria and the cell cycle. This evidence indicates bidirectional cross-talk where mitochondria function can regulate the cell cycle and induce genomic instability, and conversely, the cell cycle machinery regulates mitochondria function. Implications for this cross-talk in the development of cancer are discussed.
\end{abstract}

Keywords: Mitochondria dynamics, cell cycle, mitochondria heterogeneity, genomic heterogeneity

\section{INTRODUCTION}

Changes in metabolism and genomic instability were among the earliest characteristics of tumors to be identified. Boveri's hypothesis in the early 1900s that malignant tumors originated from cells with abnormal chromosome numbers ${ }^{[1]}$, initiated an era of research on the role of genomic instability in cancer development. Likewise, Otto Warburg's work on the metabolic changes in tumor cells $s^{[2,3]}$ pioneered an era of research studying the role of changes in cell metabolism during cancer progression. These two fields, however, have mostly remained separate. Here we focus on emerging evidence of crosstalk between the processes occurring at the mitochondria and those in the nucleus, particularly as it relates to the cell cycle. These discoveries

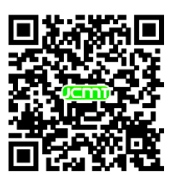


suggest an important connection between mitochondria heterogeneity and genomic heterogeneity that has key implications for our understanding of cancer development.

\section{GENOMIC INSTABILITY IN CANCERS}

Genomic instability has long been associated with cancer development ${ }^{[4]}$ and can range from single point mutations ${ }^{[5,6]}$ to massive genomic rearrangements (e.g., chromothripsis) ${ }^{[, 8]}$. Parallel genome sequencing studies of cancer cells have revealed a wide variety of mutations and chromosomal abnormalities existent in cancer genomes: studies looking at mutations identified averages of 47-84 non-silent clonal mutations per tumor ${ }^{[9]}$. Studies focusing on clonal somatic chromosomal rearrangements have uncovered similar variation, from cancer cells containing a single chromosomal rearrangement per cell to cells with $>200$ rearrangements, including deletions, duplications, and inversions ${ }^{[1,111]}$. Similarly, studies looking at gene copy number abnormalities identified a mean of 209 somatic copy number abnormalities per cancer genome $e^{[12]}$. A common finding throughout these studies is the great heterogeneity in the type of genomic instability as well as in the identity of the genes affected, with only a small number of genes found to be commonly affected in multiple cancers.

The complexity of genomic heterogeneity in cancer is further expanded when we consider that these differences are not limited to differences among clonal populations of cancer cells (inter-tumoral heterogeneity). Sequencing of different regions within a tumor reveals equally staggering intra-tumor genomic heterogeneity ${ }^{[13-17]}$, which is dynamic over time ${ }^{[18-22]}$. Taken together, these results are consistent with models of rapid genomic evolution within tumors and intra-tumoral genomic heterogeneity increasing over time, correlating with tumor aggressiveness and decreased patient survival ${ }^{[23,24]}$.

Genomic instability can be initiated by exogenous or endogenous agents. The role of external genotoxic agents (e.g., UV-light, $\mathrm{x}$-rays, chemical mutagens) in inducing genomic changes has been extensively reviewed elsewhere ${ }^{[25-28]}$. Endogenous causes of genomic instability include errors in DNA replication ${ }^{[29]}$, transcriptioninduced stress ${ }^{[30]}$, spontaneous or activation-induced cytosine deamination ${ }^{[31]}$, transposon mobilization ${ }^{[32]}$, and defective or error-prone DNA repair ${ }^{[33]}$, among other factors. Another important and widely studied source of genomic instability is DNA damage induced by the reactive oxygen species (ROS) produced in the mitochondria during the respiration process. ROS function in the cell as signaling molecules that regulate multiple cellular pathways and are key for cell and organism homeostasis ${ }^{[34]}$. However, ROS can also generate direct DNA damage by oxidation of DNA bases ${ }^{[35,36]}$. Importantly, the complex relationship between mitochondria function and nuclear processes extends beyond the role of ROS.

\section{MITOCHONDRIA HETEROGENEITY IN CANCER}

In addition to their role as the bioenergetics center of the cell, mitochondria are central to a myriad of cellular functions including iron ${ }^{[37]}$ and calcium homeostasis ${ }^{[38]}$, metabolism of amino acids, lipids, nucleotides and carbohydrates, apoptosis, and a variety of signaling pathways ${ }^{[38-42]}$. Dysfunctions in many of these mitochondrial processes have been associated with cancer development ${ }^{[40,42]}$ and chemoresistance ${ }^{[43]}$.

Similar to nuclear genomic heterogeneity, metabolic heterogeneity is also widespread in tumors. The initial findings by Otto Warburg of metabolic changes in cancer cells have been confirmed at multiple levels, from in vitro cancer cell models to in situ tumors in patients right before surgery ${ }^{[44,45]}$. Similar to the observations in genomic heterogeneity, these studies have revealed metabolic heterogeneity within different sections of the tumor ${ }^{[4]}$ indicating that metabolic heterogeneity exists between tumors (inter-tumoral), within the tumor (intra-tumoral) and most likely also varies dynamically over time.

At the genetic level, comparisons using full genome sequencing in patient-derived pairs of cancer and normal tissues across multiple tumor types revealed the existence of somatic mtDNA mutations in a majority of 
tumors ${ }^{[46,4]}$, with $31.1 \%$ of the tumors harboring multiple mtDNA mutations ${ }^{[47]}$. Unlike the nuclear genome, which contains two alleles of each gene, the mtDNA complement of a cell consists of hundreds to thousands of circular mtDNA molecules, allowing for different layers of mtDNA heterogeneity: alterations in mtDNA copy number, mutations in the mtDNA that occur in some but not all copies of the mtDNA genome within a cell (heteroplasmy), or mutations in the mtDNA that show dominance and accumulate until the mutant mtDNA becomes the only version present in the cell (homeoplasmy). Differences in mtDNA copy number, both increases and decreases of mtDNA relative to normal tissue, have been observed in many cancer types with some studies showing mtDNA copy number variation in up to $88 \%$ of tumors ${ }^{[48]}$. However, the role of mtDNA mutations or copy number variations as potential causative agents in cancer development have not been fully established due to the technological difficulties of manipulating the mtDNA genome. Studies in mice that have mtDNA from one strain and nuclear DNA from another strain (i.e., mice generated by mitochondrial-nuclear exchange) show effects in cancer progression models including changes in tumor size and metastatic burden ${ }^{[49]}$, suggesting that the mtDNA can affect cancer progression.

\section{INTERPLAY BETWEEN MITOCHONDRIA AND NUCLEAR FUNCTIONS}

Genetic interconnections between the nucleus and the mitochondria are evident, since all but thirteen mitochondrial proteins are encoded by the nuclear genome. Associations between nuclear-encoded mitochondrial genes and tumorigenesis have been found, including mutations in several subunits of complex II, succinate dehydrogenase and isocitrate dehydrogenase, among other mitochondrial enzymes ${ }^{[0,51]}$. This nuclear control of the mitochondria by regulation of nuclear-encoded mitochondrial genes is termed anterograde signaling, and it is complemented by an equally important retrograde signaling system that allows the mitochondria to relay signals to the nucleus ${ }^{[2,53]}$. Retrograde signaling was first identified via changes observed in transcription of nuclear genes in response to respiration defects ${ }^{[54]}$. Later studies established that the retrograde signaling response is a mitochondria quality control mechanism in which the cell senses different mitochondrial functions (e.g., ROS production, the TCA cycle, calcium levels, the unfolded protein response), and communicates the status of these functions to the nucleus via signaling $\operatorname{cascades}^{[52,53]}$. These retrograde signals activate diverse nuclear responses, setting in motion multiple pathways that regulate energy homeostasis, oxidative stress, and mitophagy, among other functions ${ }^{[2,53,55]}$.

Importantly, mitochondria-dependent regulation of other nucleo-centric processes has started to emerge, including a role in regulation of the cell cycle.

\section{THE MITOCHONDRIA MEETS THE CELL CYCLE}

The eukaryotic cell cycle consists of four phases G1, S-phase, G2 and mitosis. These phases were historically defined by two genome-centric processes: DNA duplication (S-phase) and chromosome segregation (mitosis), interspersed with "gap" phases (G1 and G2) to allow for cell growth ${ }^{[56]}$. It is now understood that the cell cycle involves more than duplication and segregation of DNA. During a cell cycle cells must also grow and segregate their organelles and other cellular structures ${ }^{[57-59]}$. This duplication of the genome and increase in cell biomass, followed by the complex division of all cell contents to form two fully functional daughter cells requires a large amount of energy and metabolites. Links between metabolism and the cell cycle were identified early in the history of cell cycle research via genetic screens in budding yeast that identified Cell Division Cycle (CDC) mutants ${ }^{[60]}$. Several of the original CDC alleles, which cause cell cycle defects when grown at the non-permissive temperature, were later discovered to also result in reduced carbon metabolism and lower ATP production ${ }^{[6]]}$. Conversely, mutations in cell cycle genes, such as the cyclin-dependent kinase CDC28 were found to also affect mitochondria biogenesis ${ }^{[62]}$.

This metabolism-cell cycle connection has been studied in detail in budding yeast. Analysis of synchronously growing yeast populations uncovered cyclic changes of metabolism that associate closely with the phases 
of the cell cycle ${ }^{[63]}$. These studies determined that in budding yeast the metabolic cycle consists of three phases $^{[64]}$ : (1) oxidative respiration, marked by increased oxidative phosphorylation, increased ATP and amino acid production. This phase is aligned with entry and progression into G1 of the cell cycle; (2) reductive/building phase, characterized by an increase in glycolysis, increased production of nucleotides, nucleosides and ethanol. This phase occurs in synchrony with S-phase and mitosis; (3) reductive/charging characterized by production of complex carbohydrates for energy storage (e.g., glycogen, trehalose). This phase occurs during the end of mitosis and entry into quiescence (Go). The synchronicity of the cell cycle and metabolic cycle in budding yeast appears to be the result of a system of coupled oscillators, since the metabolic cycle can continue to oscillate in the absence of cell division ${ }^{[65,66]}$. Intriguingly, the expression of a number of cell cycle genes continues to oscillate with the metabolic cycle even in those cells that are not undergoing cell division, suggesting that the metabolic cycle can regulate cyclic expression of cell cycle genes independently of cell cycle controls ${ }^{[65]}$.

Overall the evidence in budding yeast reveals an interaction between mitochondrial metabolism and the cell cycle. Evidence of a similar interaction in other organisms has only recently started to emerge.

\section{MITOCHONDRIA DYNAMICS ARE REGULATED BY THE CELL CYCLE}

Early studies on the connection between mitochondria processes and the cell cycle in human cells identified an increase in total mitochondria biomass that paralleled the increase in cell size during cell cycle progression $^{[67]}$. The finding that mtDNA replication was not co-regulated with nuclear DNA replication ${ }^{[68]}$, led to the idea that mitochondria and cell cycle processes were mostly unlinked. This view has changed recently as mounting evidence has shown that mitochondria biogenesis, morphology, dynamics and function are regulated by the cell cycle.

Mitochondria are highly dynamic organelles undergoing constant fission and fusion. These dynamics depend largely on several members of the dynamin family of proteins: mitofusin 1 and $2(\mathrm{Mfn} 1 / 2)$ drive fusion of the outer mitochondria membrane and optic atrophy protein 1 (Opa1) mediates inner mitochondria membrane fusion, while dynamin-related protein 1 (Drp1) is required for mitochondria fission ${ }^{[6,70]}$. Mitochondria fission is also facilitated by four receptors that cooperate to recruit Drp1 to the outer mitochondria membrane: Mff, MiD49/51 and Fis $1^{[71,72]}$. Importantly, mitochondria morphology and dynamics change in a cell cycledependent manner ${ }^{[73]}$, with elongated mitochondria being dominant in $\mathrm{Gl}^{[74]}$ and short mitochondria being dominant in mitosis ${ }^{[75]}$. These changes in mitochondria dynamics during the cell cycle are controlled via regulation of mitochondria-dynamics proteins by the cell cycle machinery [Figure 1].

Mitochondria fission during mitosis in human cells is driven by Drp1, whose activity is increased in mitosis via phosphorylation by the mitotic cyclin Cyclin $\mathrm{B} 1 / \mathrm{Cdk}_{1}{ }^{[76]}$. Drp1 phosphorylation in mitosis is promoted by another mitotic kinase, Aurora A, via phosphorylation of the small GTPase RALA and its binding partner RALBP1, which in turn bind to and facilitate Drp1 phosphorylation by Cyclin B1/Cdk1 ${ }^{[77]}$. Mitochondria fission in mitosis is important for mitochondria segregation. Depletion of RALA or RALBP1 result in asymmetric segregation of the mitochondria to the two daughter cells, presence of mitochondria bridges during cytokinesis, and in some cases cytokinesis failure due to interference of the indivisible mitochondria mass with the cytokinetic ring ${ }^{[77]}$. In turn, Drp1 promotes mitotic exit (adaptation) of cells arrested in mitosis with the microtubule-stabilizing drug taxol via regulation of Cyclin B1 levels ${ }^{[78]}$. Similarly, ATP depletion by addition of 2-deoxy-glucose (2-DG) and sodium azide promotes mitotic exit in cells arrested in mitosis with the microtubule depolymerizing drug nocodazole, and this adaptation is also due to reduction in Cyclin B levels ${ }^{[7]}$. These results indicate a bi-directional crosstalk where the mitotic machinery increases Drp1 activity and mitochondria dynamics in mitosis, which in turn feedbacks to regulate mitosis ${ }^{[80]}$. Once the cells exit mitosis, Drp1 is targeted for degradation by APC/C $\mathrm{C}^{\mathrm{Cdh} 1[81]}$, shifting the balance of mitochondria dynamics to favor mitochondria fusion. 


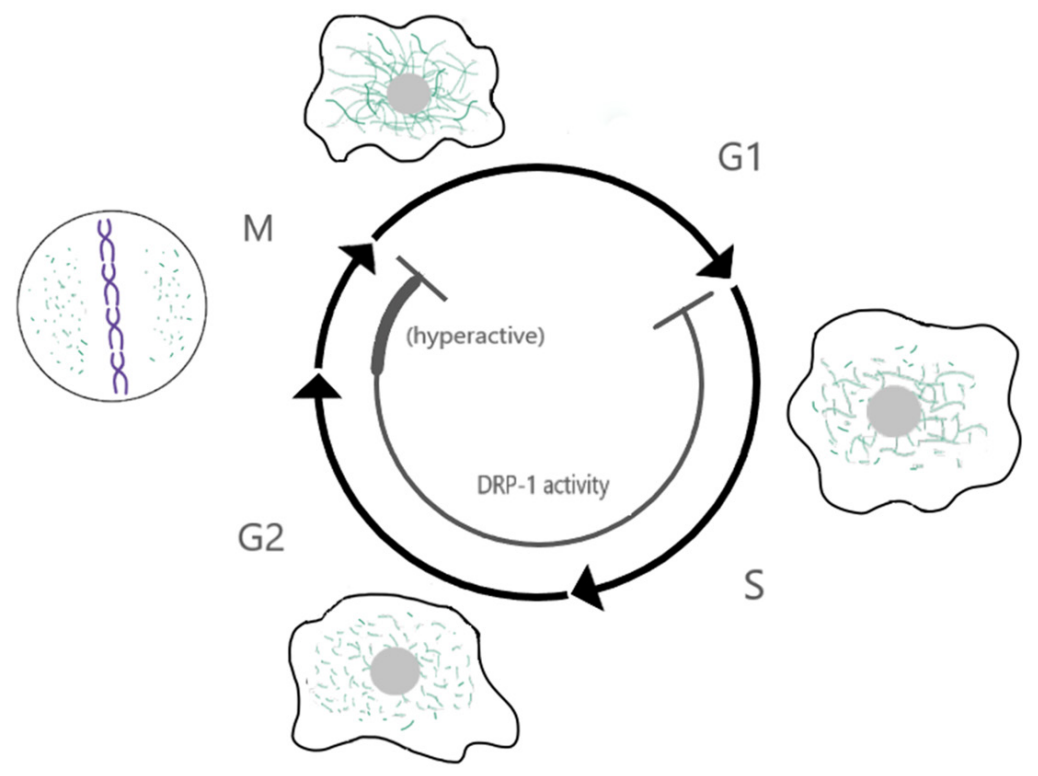

Figure 1. Crosstalk between mitochondria dynamics and the cell cycle. Model showing the changes in mitochondria dynamics and Drp1 activity throughout the cell cycle. Mitochondria fusion is favored in G1 and mitochondria fission is dominant in mitosis. This leads to the formation of a highly elongated and interconnected network during late G1, and small disconnected mitochondria in mitosis. Changes in mitochondria dynamics are regulated by the cell cycle machinery, for example mitochondria fission is favored in mitosis by Drp1 phosphorylation by the mitotic kinase Cyclin B1/Cdk1. Conversely, mitochondria fusion is favored in G1 due, at least in part, to degradation of Drp1 by the ubiquitin ligase $\mathrm{APC} / \mathrm{C}-\mathrm{Cdh} 1$ in early $\mathrm{G} 1$. In turn, these changes in mitochondria morphology regulate the cell cycle. Hyperfused mitochondria promote the G1/S transition, while inhibition of Drp1 induces a G2 arrest and failure to fragment mitochondria in mitosis can interfere with cytokinesis. These phenotypes have started to reveal a profound level of cross-talk between these two processes

In addition to regulating mitochondria dynamics, cell cycle proteins also regulate respiration and other mitochondrial processes. Cyclin D1 represses mitochondria function by inhibiting nuclear respiratory factor 1 (NRF1), a transcription factor that induces expression of a set of nuclear-encoded mitochondrial genes ${ }^{[82]}$, and regulates gluconeogenesis ${ }^{[83]}$. A pool of Cyclin B1/Cdk1 localizes to the mitochondria, phosphorylates components of the OXPHOS machinery and increases their activity at the G2/M transition ${ }^{[84]}$. Some components of the spindle assembly checkpoint (e.g., Mad2, BubR1, p31-comet) have roles in insulin signaling ${ }^{[85]}$, while others (e.g., Mps1, Survivin) localize to the mitochondria and regulate apoptosis ${ }^{[86,87]}$. Together, these results indicate extensive regulation of mitochondria functions and/or cell metabolism by the cell cycle machinery.

\section{THE CELL CYCLE IS IN TURN REGULATED BY MITOCHONDRIA FUNCTION}

Increased mitochondria fusion after mitotic exit leads to the formation of a hyperfused mitochondria network in late G1 which promotes the transition from G1 into S-phase $\mathrm{e}^{[74]}$. The molecular mechanism by which mitochondria hyperfusion promotes S-phase entry has not been completely elucidated. However, it appears that mitochondria hyperfusion and the accompanying increase in mitochondria respiration in late G1 promotes accumulation of the S-phase cyclin, Cyclin $E^{[74]}$. Conversely, inhibition of respiration in G1 using the uncouplers FCCP or CCCP results in decreased Cyclin E accumulation and delay in S-phase entry ${ }^{[7,88]}$. This model is supported by an analysis of mitochondrial potential $(\Delta \Psi \mathrm{m})$ in a population of $\mathrm{G} 1$ cells which showed that $\mathrm{G} 1$ cells with low $\Delta \Psi \mathrm{m}$ have a molecular profile corresponding to early $\mathrm{G} 1$ cells (e.g., low Cyclin E, high p27Kip1), while G1 cells with high $\Delta \Psi \mathrm{m}$ have a late $\mathrm{G} 1$ molecular signature (e.g., high Cyclin E, low p27Kip1) ${ }^{[89]}$.

In addition to its role in promoting the G1/S transition, mitochondria dynamics also regulate the G2/M transition. Depletion of Drp1 results in a G2 arrest ${ }^{[90-92]}$, due to the presence of DNA damage and activation 
of the DNA-damage kinases ATM and $\mathrm{ATR}^{[90]}$. A similar G2 delay accompanied by DNA damage is also observed after disruption of the Drp1 adaptor Fis $1^{[93]}$. Disruption of other mitochondria functions, such as in a Drosophila knockout of the mitochondria-specific form of RNase $Z^{[94]}$ and in human cells depleted of mtDNA (rhoo cells) ${ }^{[95]}$ also cause a G2 delay. Furthermore the G2 delay after Fis1 depletion correlates with low expression of the cell cycle transcription factor FoxM1 and its downstream mitotic genes, including Cyclin B1, suggesting that defects in mitochondria dynamics/function can lead to transcriptional inhibition of the G2/M transition ${ }^{[93]}$. The link between mitochondria dynamics and cell cycle gene expression is further strengthened by observations of a correlation between Drp1 expression levels and expression of cell cycle genes in different cancers, particularly genes expressed in $\mathrm{G}_{2} / \mathrm{M}^{[96]}$. Other metabolic alterations such as starvation and the subsequent induction of autophagy, or hypoxia have also been shown to regulate cell cycle progression ${ }^{[9]]}$.

Mitochondria dynamics/function have a role in the regulation of mitosis since Drp1 activity and ATP depletion promote mitotic exit in cells arrested in mitosis with microtubule-targeting drugs ${ }^{[78,79]}$. This exit from mitotic arrest when mitochondria function is compromised is due to premature degradation of Cyclin $\mathrm{B} 1$ by activation of the ubiquitin ligase $\mathrm{APC} / \mathrm{C}^{\mathrm{Cdh}\left[{ }^{179]}\right.}$. These results indicate a complex cross-talk between mitochondria functions and the mitotic machinery, which has important implications for our understanding of the response of cancer cells to microtubule-targeting agents commonly used as cancer treatments (e.g., taxol, vinblastine). Additionally, other mitotic phenotypes are observed in cells with compromised mitochondria function, including amplification of centrosomes ${ }^{[00,95]}$, abnormal centrosome positioning ${ }^{[98]}$, chromosome misalignment ${ }^{[90]}$ and multipolar spindles ${ }^{[95]}$. However, whether these phenotypes indicate a role for the mitochondria in the regulation of centrosome duplication or mitosis, or are merely consequences of the G2 delay and DNA damage observed in these cells has not been elucidated. Paradoxically, incubation with the Drp1 inhibitor Mdivi-1 seems to exert the opposite effect in cells damaged by x-rays. X-ray irradiation results in DNA damage, abnormal progression through mitosis (mitotic catastrophe), centrosome amplification and formation of micronuclei. In this scenario, incubation with the Drp1 inhibitor Mdivi-1 reduced the centrosome amplification and formation of micronuclei observed after irradiation ${ }^{[99]}$.

Taken together, these results provide clear evidence of a bidirectional link between mitochondria dynamics/ function and cell cycle progression at multiple phases. However, more research is needed to fully understand the extent of interaction between these processes and to understand the molecular underpinnings of this crosstalk.

\section{OTHER LINKS BETWEEN THE MITOCHONDRIA AND NUCLEAR FUNCTION}

As discussed previously, one of the best studied endogenous sources of genomic instability is the mutagenic potential of ROS, which can induce oxidative DNA damage ${ }^{[35,36]}$. Increased levels of ROS have also been shown to induce other types of damage such as telomere attrition and chromosome fusions ${ }^{[100]}$. However, other mechanisms by which mitochondrial dysfunction affects nuclear genome instability have started to emerge [Figure 2]. In budding yeast, loss of mtDNA leads to genomic instability and this was not correlated with defects in respiration, but rather with defects on the mitochondrial processing of iron-sulfur clusters ${ }^{[101]}$. In addition, mtDNA can affect nuclear DNA through direct transfer of genes. This process, termed numtogenesis ${ }^{[102]}$, was thought to be a rare event occurring at an evolutionary scale of millions of years. However, several reports have identified higher rates of numtogenesis in cancer cells. For example, a study identified mtDNA in the nuclei of up to $27.5 \%$ of cervical carcinoma cells compared to $0 \%$ of paired cells from the normal cervical epithelium ${ }^{[103]}$. Increased rates of numtogenesis were also observed via analysis of whole genome sequencing of adenocarcinoma samples ${ }^{[104]}$. Importantly, mtDNA integration into the nuclear genome can have important consequences such as activation of oncogenes ${ }^{[105]}$.

Another direct link between the mitochondria and genomic instability has been observed in cells that survive exposure to pro-apoptotic stimuli. Exposure of cells to a sub-lethal dose of the BH3-mimetic ABT737 results 


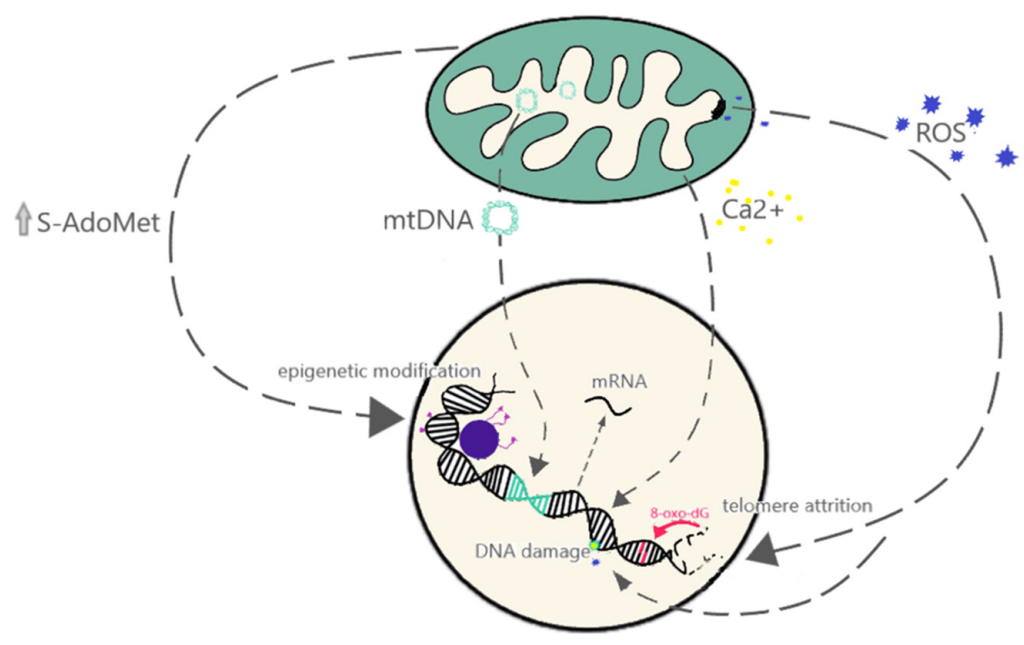

Figure 2. Mitochondria functions impact nuclear functions. Model showing the different aspects of mitochondria function that have been shown to affect the nuclear genome at the level of gene expression (e.g., via calcium signaling pathways), genomic instability (e.g., DNA damage, telomere attrition) or epigenetic modifications (e.g., DNA methylation, histone modifications)

in partial mitochondria outer membrane permeabilization (MOMP), partial caspase activation and increased DNA damage ${ }^{[106]}$. One of the mitochondrial proteins, released from the mitochondria during MOMP is apoptosis inducing factor (AIF). AIF translocates to the nucleus and binds to the nuclear DNA, triggering condensation and fragmentation ${ }^{[107-109]}$. Importantly this nuclear translocation of AIF has also been observed in cells exposed to sublethal doses of oxidative stress $^{[110]}$, suggesting that release of mitochondrial proteins like AIF can result in DNA damage without triggering apoptosis.

In addition to introducing genomic instability, the mitochondria also modulates nuclear functions via retrograde signaling that regulates nuclear gene expression. Mitochondria play a role in the epigenetic regulation of the nuclear genome ${ }^{[111,112]}$. DNA methylation patterns have been shown to change in cells depleted of mtDNA (rhoo) $)^{[113]}$ and in cells with different mtDNA haplotypes ${ }^{[114]}$. Mitochondria also have a role in calcium regulation, and mitochondrial stress can induce calcium release, activating signaling cascades that can lead to different nuclear gene expression responses and phenotypic changes, such as increases in invasive behavior ${ }^{[115]}$. Similarly, reduction in mtDNA content in breast cancer cells activates a calcineurindependent pathway that induces phenotypic changes similar to the epithelial-to-mesenchymal transition (EMT) associated with higher cancer aggressiveness ${ }^{[116]}$. Retrograde signaling, alteration of epigenetic regulation, direct transfer of genetic material, and ROS-mediated effects demonstrate the myriad of ways that mitochondrial dysfunction can play a role in nuclear genome instability and function.

\section{IMPLICATIONS OF MITOCHONDRIA-NUCLEAR INTERACTIONS FOR CANCER}

Deregulation of cellular energetics is considered one of the emerging hallmarks of tumor development, while genomic instability has been established as an enabling characteristic of cancers ${ }^{[117]}$. The results discussed in this review provide evidence for a complex bidirectional cross-talk between mitochondria processes and nuclear processes involved in genomic maintenance, particularly regulation of the cell cycle. Identifying the molecular players involved in this cross-talk will not only open possibilities for the development of new cancer treatments, but it also reveals an unexpected complexity where genomic instability and defects in mitochondria function can synergize to accelerate cancer progression. That is, as cancer progresses and cell metabolism changes, these changes could lead to modifications in cell proliferation due to cell cycle dysregulation; while in turn modifications in the cell cycle or genomic instability can induce changes in mitochondria function, leading to a synergistic acceleration in the acquisition of cancer-associated traits. 
This synergism also accelerates the acquisition of heterogeneity whereby increases in genomic heterogeneity will promote heterogeneity of mitochondria function, and vice versa.

\section{DECLARATIONS}

\section{Acknowledgments}

The authors would like to thank Dr. Sid Das and the Das lab for continuous support and helpful discussions.

\section{Authors' contributions}

All authors contributed to the writing of this review. In addition Herrera EL prepared the figures.

\section{Availability of data and materials}

Not applicable.

\section{Financial support and sponsorship}

Work in our laboratory is partially funded by UTEP's Research Incentive Program and a grant to LADM from BD-Biosciences. Herrera EL is an NIGS RISE-scholar funded by grant R25GM069621-11. Azzam SZ is an NSF S-STEM scholar funded by grant DUE1565063.

\section{Conflicts of interest}

All authors declared that there are no conflicts of interest.

\section{Ethical approval and consent to participate}

Not applicable.

\section{Consent for publication}

Not applicable.

\section{Copyright}

(c) The Author(s) 2018.

\section{REFERENCES}

1. Boveri T. Concerning the origin of malignant tumours by Theodor Boveri. Translated and annotated by Henry Harris. J Cell Sci 2008;121 Suppl 1:1-84.

2. Warburg O, Wind F, Negelein E. The metabolism of tumors in the body. J Gen Physiol 1927;8:519-30.

3. Warburg O. On the origin of cancer cells. Science 1956;123:309-14.

4. Nowell PC. The clonal evolution of tumor cell populations. Science 1976;194:23-8.

5. Reddy EP, Reynolds RK, Santos E, Barbacid M. A point mutation is responsible for the acquisition of transforming properties by the T24 human bladder carcinoma oncogene. Nature 1982;300:149-52.

6. Srivastava S, Zou Z, Pirollo K, Blattner W, Chang EH. Germ-line transmission of a mutated p53 gene in a cancer-prone family with LiFraumeni syndrome. Nature 1990;348:747-9.

7. Stephens PJ, Greenman CD, Fu B, Yang F, Bignell GR, Mudie LJ, Pleasance ED, Lau KW, Beare D, Stebbings LA, McLaren S, Lin ML, McBride DJ, Varela I, Nik-Zainal S, Leroy C, Jia M, Menzies A, Butler AP, Teague JW, Quail MA, Burton J, Swerdlow H, Carter NP, Morsberger LA, Iacobuzio-Donahue C, Follows GA, Green AR, Flanagan AM, Stratton MR, Futreal PA, Campbell PJ. Massive genomic rearrangement acquired in a single catastrophic event during cancer development. Cell 2011;144:27-40.

8. Crasta K, Ganem NJ, Dagher R, Lantermann AB, Ivanova EV, Pan Y, Nezi L, Protopopov A, Chowdhury D, Pellman D. DNA breaks and chromosome pulverization from errors in mitosis. Nature 2012;482:53-8.

9. Salk JJ, Fox EJ, Loeb LA. Mutational heterogeneity in human cancers: origin and consequences. Annu Rev Pathol Mech Dis 2010;5:51-75.

10. Campbell PJ, Stephens PJ, Pleasance ED, O’Meara S, Li H, Santarius T, Stebbings LA, Leroy C, Edkins S, Hardy C, Teague JW, Menzies A, Goodhead I, Turner DJ, Clee CM, Quail MA, Cox A, Brown C, Durbin R, Hurles ME, Edwards PA, Bignell GR, Stratton MR, Futreal PA. Identification of somatically acquired rearrangements in cancer using genome-wide massively parallel paired-end sequencing. Nat Genet 2008;40:722-9.

11. Stephens PJ, McBride DJ, Lin ML, Varela I, Pleasance ED, Simpson JT, Stebbings LA, Leroy C, Edkins S, Mudie LJ, Greenman CD, 
Jia M, Latimer C, Teague JW, Lau KW, Burton J, Quail MA, Swerdlow H, Churcher C, Natrajan R, Sieuwerts AM, Martens JW, Silver DP, Langerød A, Russnes HE, Foekens JA, Reis-Filho JS, van 't Veer L, Richardson AL, Børresen-Dale AL, Campbell PJ, Futreal PA, Stratton MR. Complex landscapes of somatic rearrangement in human breast cancer genomes. Nature 2009;462:1005-10.

12. Smida J, Xu H, Zhang Y, Baumhoer D, Ribi S, Kovac M, von Luettichau I, Bielack S, O’Leary VB, Leib-Mösch C, Frishman D, Nathrath M. Genome-wide analysis of somatic copy number alterations and chromosomal breakages in osteosarcoma. Int J Cancer 2017;141:816-28.

13. Zhang LL, Kan M, Zhang MM, Yu SS, Xie HJ, Gu ZH, Wang HN, Zhao SX, Zhou GB, Song HD, Zheng CX. Multiregion sequencing reveals the intratumor heterogeneity of driver mutations in TP53-driven non-small cell lung cancer. Int J Cancer 2017;140:103-8.

14. Gerlinger M, Rowan AJ, Horswell S, Math M, Larkin J, Endesfelder D, Gronroos E, Martinez P, Matthews N, Stewart A, Tarpey P, Varela I, Phillimore B, Begum S, McDonald NQ, Butler A, Jones D, Raine K, Latimer C, Santos CR, Nohadani M, Eklund AC, Spencer-Dene B, Clark G, Pickering L, Stamp G, Gore M, Szallasi Z, Downward J, Futreal PA, Swanton C. Intratumor heterogeneity and branched evolution revealed by multiregion sequencing. N Engl J Med 2012;366:883-92.

15. Martinez P, Birkbak NJ, Gerlinger M, McGranahan N, Burrell RA, Rowan AJ, Joshi T, Fisher R, Larkin J, Szallasi Z, Swanton C. Parallel evolution of tumour subclones mimics diversity between tumours. J Pathol 2013;230:356-64.

16. Rasche L, Chavan SS, Stephens OW, Patel PH, Tytarenko R, Ashby C, Bauer M, Stein C, Deshpande S, Wardell C, Buzder T, Molnar G, Zangari M, van Rhee F, Thanendrarajan S, Schinke C, Epstein J, Davies FE, Walker BA, Meissner T, Barlogie B, Morgan GJ, Weinhold N. Spatial genomic heterogeneity in multiple myeloma revealed by multi-region sequencing. Nat Commun 2017;8:268.

17. Jamal-Hanjani M, Wilson GA, McGranahan N, Birkbak NJ, Watkins TBK, Veeriah S, Shafi S, Johnson DH, Mitter R, Rosenthal R, Salm M, Horswell S, Escudero M, Matthews N, Rowan A, Chambers T, Moore DA, Turajlic S, Xu H, Lee SM, Forster MD, Ahmad T, Hiley CT, Abbosh C, Falzon M, Borg E, Marafioti T, Lawrence D, Hayward M, Kolvekar S, Panagiotopoulos N, Janes SM, Thakrar R, Ahmed A, Blackhall F, Summers Y, Shah R, Joseph L, Quinn AM, Crosbie PA, Naidu B, Middleton G, Langman G, Trotter S, Nicolson M, Remmen H, Kerr K, Chetty M, Gomersall L, Fennell DA, Nakas A, Rathinam S, Anand G, Khan S, Russell P, Ezhil V, Ismail B, Irvin-Sellers M, Prakash V, Lester JF, Kornaszewska M, Attanoos R, Adams H, Davies H, Dentro S, Taniere P, O’Sullivan B, Lowe HL, Hartley JA, Iles N, Bell H, Ngai Y, Shaw JA, Herrero J, Szallasi Z, Schwarz RF, Stewart A, Quezada SA, Le Quesne J, Van Loo P, Dive C, Hackshaw A, Swanton C; TRACERx Consortium. Tracking the evolution of non-small-cell lung cancer. N Engl J Med 2017;376:2109-21.

18. Zhao Z, Goldin L, Liu S, Wu L, Zhou W, Lou H, Yu Q, Tsang SX, Jiang M, Li F, McMaster M, Li Y, Lin X, Wang Z, Xu L, Marti G, Li G, Wu K, Yeager M, Yang H, Xu X, Chanock SJ, Li B, Hou Y, Caporaso N, Dean M. Evolution of multiple cell clones over a 29-year period of a CLL patient. Nat Commun 2016;7:13765.

19. Bolli N, Avet-Loiseau H, Wedge DC, Van Loo P, Alexandrov LB, Martincorena I, Dawson KJ, Iorio F, Nik-Zainal S, Bignell GR, Hinton JW, Li Y, Tubio JM, McLaren S, O’ Meara S, Butler AP, Teague JW, Mudie L, Anderson E, Rashid N, Tai YT, Shammas MA, Sperling AS, Fulciniti M, Richardson PG, Parmigiani G, Magrangeas F, Minvielle S, Moreau P, Attal M, Facon T, Futreal PA, Anderson KC, Campbell PJ, Munshi NC. Heterogeneity of genomic evolution and mutational profiles in multiple myeloma. Nat Commun 2014;5:2997.

20. Keats JJ, Chesi M, Egan JB, Garbitt VM, Palmer SE, Braggio E, Van Wier S, Blackburn PR, Baker AS, Dispenzieri A, Kumar S, Rajkumar SV, Carpten JD, Barrett M, Fonseca R, Stewart AK, Bergsagel PL. Clonal competition with alternating dominance in multiple myeloma. Blood 2012;120:1067-76.

21. Shah SP, Morin RD, Khattra J, Prentice L, Pugh T, Burleigh A, Delaney A, Gelmon K, Guliany R, Senz J, Steidl C, Holt RA, Jones S, Sun M, Leung G, Moore R, Severson T, Taylor GA, Teschendorff AE, Tse K, Turashvili G, Varhol R, Warren RL, Watson P, Zhao Y, Caldas C, Huntsman D, Hirst M, Marra MA, Aparicio S. Mutational evolution in a lobular breast tumour profiled at single nucleotide resolution. Nature 2009;461:809-13.

22. Thomsen MBH, Nordentoft I, Lamy P, Høyer S, Vang S, Hedegaard J, Borre M, Jensen JB, Ørntoft TF, Dyrskjøt L. Spatial and temporal clonal evolution during development of metastatic urothelial carcinoma. Mol Oncol 2016;10:1450-60.

23. Mroz EA, Tward AM, Hammon RJ, Ren Y, Rocco JW. Intra-tumor genetic heterogeneity and mortality in head and neck cancer: analysis of data from the Cancer Genome Atlas. PLoS Med 2015;12:e1001786.

24. Sveen A, Løes IM, Alagaratnam S, Nilsen G, Høland M, Lingjærde OC, Sorbye H, Berg KC, Horn A, Angelsen JH, Knappskog S, Lønning PE, Lothe RA. Intra-patient inter-metastatic genetic heterogeneity in colorectal cancer as a key determinant of survival after curative liver resection. PLoS Genet 2016;12:e1006225.

25. Sedgwick B. Repairing DNA-methylation damage. Nat Rev Mol Cell Biol 2004;5:148-57.

26. Pfeifer GP. How the environment shapes cancer genomes. Curr Opin Oncol 2015;27:71-7.

27. Poirier MC. Linking DNA adduct formation and human cancer risk in chemical carcinogenesis. Environ Mol Mutagen 2016;57:499-507.

28. Poon S, McPherson JR, Tan P, Teh BT, Rozen SG. Mutation signatures of carcinogen exposure: genome-wide detection and new opportunities for cancer prevention. Genome Med 2014;6:24.

29. Aguilera A, García-Muse T. Causes of genome instability. Annu Rev Genet 2013;47:1-32.

30. Tubbs A, Nussenzweig A. Endogenous DNA damage as a source of genomic instability in cancer. Cell 2017;168:644-56.

31. Olinski R, Gackowski D, Cooke MS. Endogenously generated DNA nucleobase modifications source, and significance as possible biomarkers of malignant transformation risk, and role in anticancer therapy. Biochim Biophys Acta 2018;1869:29-41.

32. Moyano M, Stefani G. piRNA involvement in genome stability and human cancer. J Hematol Oncol 2015;8:38.

33. Rodgers K, McVey M. Error-prone repair of DNA double-strand breaks. J Cell Physiol 2016;231:15-24.

34. Shadel GS, Horvath TL. Mitochondrial ROS signaling in organismal homeostasis. Cell 2015;163:560-9.

35. Sabharwal SS, Schumacker PT. Mitochondrial ROS in cancer: initiators, amplifiers or an Achilles' heel? Nat Rev Cancer 2014;14:709-21. 
36. Tokarz P, Blasiak J. Role of mitochondria in carcinogenesis. Acta Biochim Pol 2014;61:671-8.

37. Stehling O, Wilbrecht C, Lill R. Mitochondrial iron-sulfur protein biogenesis and human disease. Biochimie 2014;100:61-77.

38. Danese A, Patergnani S, Bonora M, Wieckowski MR, Previati M, Giorgi C, Pinton P. Calcium regulates cell death in cancer: roles of the mitochondria and mitochondria-associated membranes (MAMs). Biochim Biophys Acta 2017;1858:615-27.

39. Kasahara A, Scorrano L. Mitochondria: from cell death executioners to regulators of cell differentiation. Trends Cell Biol 2014;24:761.

40. Vyas S, Zaganjor E, Haigis MC. Mitochondria and cancer. Cell 2016;166:555-66.

41. Weinberg SE, Chandel NS. Targeting mitochondria metabolism for cancer therapy. Nat Chem Biol 2015;11:9-15.

42. Zong WX, Rabinowitz JD, White E. Mitochondria and cancer. Mol Cell 2016;61:667-76.

43. Guerra F, Arbini AA, Moro L. Mitochondria and cancer chemoresistance. Biochim Biophys Acta 2017;1858:686-99.

44. Hensley CT, Faubert B, Yuan Q, Lev-Cohain N, Jin E, Kim J, Jiang L, Ko B, Skelton R, Loudat L, Wodzak M, Klimko C, McMillan E, Butt Y, Ni M, Oliver D, Torrealba J, Malloy CR, Kernstine K, Lenkinski RE, DeBerardinis RJ. Metabolic heterogeneity in human lung tumors. Cell 2016;164:681-94.

45. Maher EA, Marin-Valencia I, Bachoo RM, Mashimo T, Raisanen J, Hatanpaa KJ, Jindal A, Jeffrey FM, Choi C, Madden C, Mathews D, Pascual JM, Mickey BE, Malloy CR, DeBerardinis RJ. Metabolism of [U-13 C]glucose in human brain tumors in vivo. NMR Biomed 2012;25:1234-44.

46. Stewart JB, Alaei-Mahabadi B, Sabarinathan R, Samuelsson T, Gorodkin J, Gustafsson CM, Larsson E. Simultaneous DNA and RNA mapping of somatic mitochondrial mutations across diverse human cancers. PLoS Genet 2015;11:e1005333.

47. Ju YS, Alexandrov LB, Gerstung M, Martincorena I, Nik-Zainal S, Ramakrishna M, Davies HR, Papaemmanuil E, Gundem G, Shlien A, Bolli N, Behjati S, Tarpey PS, Nangalia J, Massie CE, Butler AP, Teague JW, Vassiliou GS, Green AR, Du MQ, Unnikrishnan A, Pimanda JE, Teh BT, Munshi N, Greaves M, Vyas P, El-Naggar AK, Santarius T, Collins VP, Grundy R, Taylor JA, Hayes DN, Malkin D; ICGC Breast Cancer Group; ICGC Chronic Myeloid Disorders Group; ICGC Prostate Cancer Group; Foster CS, Warren AY, Whitaker HC, Brewer D, Eeles R, Cooper C, Neal D, Visakorpi T, Isaacs WB, Bova GS, Flanagan AM, Futreal PA, Lynch AG, Chinnery PF, McDermott U, Stratton MR, Campbell PJ. Origins and functional consequences of somatic mitochondrial DNA mutations in human cancer. Elife 2014;3:02935.

48. Hertweck KL, Dasgupta S. The landscape of mtDNA modifications in cancer: a tale of two cities. Front Oncol 2017;7:262.

49. Bussard KM, Siracusa LD. Understanding mitochondrial polymorphisms in cancer. Cancer Res 2017;77:6051-9.

50. Choudhury AR, Singh KK. Mitochondrial determinants of cancer health disparities. Semin Cancer Biol 2017;47:125-46.

51. van Gisbergen MW, Voets AM, Starmans MHW, de Coo IF, Yadak R, Hoffmann RF, Boutros PC, Smeets HJ, Dubois L, Lambin P. How do changes in the mtDNA and mitochondrial dysfunction influence cancer and cancer therapy? Challenges, opportunities and models. Mutat Res Mutat Res 2015;764:16-30.

52. Kleine T, Leister D. Retrograde signaling: organelles go networking. Biochim Biophys Acta 2016;1857:1313-25.

53. Liu Z, Butow RA. Mitochondrial retrograde signaling. Annu Rev Genet 2006;40:159-85.

54. Parikh VS, Morgan MM, Scott R, Clements LS, Butow RA. The mitochondrial genotype can influence nuclear gene expression in yeast. Science 1987;235:576-80.

55. Guha M, Avadhani NG. Mitochondrial retrograde signaling at the crossroads of tumor bioenergetics, genetics and epigenetics. Mitochondrion 2013;13:577-91.

56. Nurse P. A long twentieth century of the cell cycle and beyond. Cell 2000;100:71-8.

57. Knoblach B, Rachubinski RA. Motors, anchors, and connectors: orchestrators of organelle inheritance. Annu Rev Cell Dev Biol 2015;31:55-81.

58. Ouellet J, Barral Y. Organelle segregation during mitosis: lessons from asymmetrically dividing cells. J Cell Biol 2012;196:305-13.

59. Conduit PT, Wainman A, Raff JW. Centrosome function and assembly in animal cells. Nat Rev Mol Cell Biol 2015;16:611-24.

60. Hartwell LH, Culotti J, Pringle JR, Reid BJ. Genetic control of the cell division cycle in yeast. Science 1974;183:46-51.

61. Aon MA, Mónaco ME, Cortassa S. Carbon and energetic uncoupling are associated with block of division at different stages of the cell cycle in several cdc mutants of saccharomyces cerevisiae. Exp Cell Res 1995;217:42-51.

62. Genta HD, Mónaco ME, Aon MA. Decreased mitochondrial biogenesis in temperature-sensitive cell division cycle mutants of Saccharomyces cerevisiae. Curr Microbiol 1995;31:327-31.

63. Tu BP, Mohler RE, Liu JC, Dombek KM, Young ET, Synovec RE, McKnight SL. Cyclic changes in metabolic state during the life of a yeast cell. Proc Natl Acad Sci U S A 2007;104:16886-91.

64. Cai L, Tu BP. Driving the cell cycle through metabolism. Annu Rev Cell Dev Biol 2012;28:59-87.

65. Slavov N, Macinskas J, Caudy A, Botstein D. Metabolic cycling without cell division cycling in respiring yeast. Proc Natl Acad Sci U S A 2011;108:19090-5.

66. Papagiannakis A, Niebel B, Wit EC, Heinemann M. Autonomous metabolic oscillations robustly gate the early and late cell cycle. Mol Cell 2017;65:285-95.

67. Posakony JW, England JM, Attardi G. Mitochondrial growth and division during the cell cycle in HeLa cells. J Cell Biol 1977;74:468-91.

68. Newton CS, Fangman WL. Mitochondrial DNA synthesis in cell cycle mutants of saccharomyces cerevisiae. Cell 1975;5:423-8.

69. Smirnova E, Shurland DL, Ryazantsev SN, van der Bliek AM. A human dynamin-related protein controls the distribution of mitochondria. J Cell Biol 1998;143:351-8.

70. Smirnova E, Griparic L, Shurland DL, van der Bliek AM. Dynamin-related protein Drp1 is required for mitochondrial division in mammalian cells. Mol Biol Cell 2001;12:2245-56.

71. Osellame LD, Singh AP, Stroud DA, Palmer CS, Stojanovski D, Ramachandran R, Ryan MT. Cooperative and independent roles of the 
Drp1 adaptors Mff, MiD49 and MiD51 in mitochondrial fission. J Cell Sci 2016;129:2170-81.

72. Loson OC, Song Z, Chen H, Chan DC. Fis1, Mff, MiD49, and MiD51 mediate Drp1 recruitment in mitochondrial fission. Mol Biol Cell 2013;24:659-67.

73. Arakaki N, Nishihama T, Owaki H, Kuramoto Y, Suenaga M, Miyoshi E, Emoto Y, Shibata H, Shono M, Higuti T. Dynamics of mitochondria during the cell cycle. Biol Pharm Bull 2006;29:1962-5.

74. Mitra K, Wunder C, Roysam B, Lin G, Lippincott-Schwartz J. A hyperfused mitochondrial state achieved at G1-S regulates cyclin E buildup and entry into S phase. Proc Natl Acad Sci U S A 2009;106:11960-5.

75. Lee S, Kim S, Sun X, Lee JH, Cho H. Cell cycle-dependent mitochondrial biogenesis and dynamics in mammalian cells. Biochem Biophys Res Commun 2007;357:111-7.

76. Taguchi N, Ishihara N, Jofuku A, Oka T, Mihara K. Mitotic phosphorylation of dynamin-related GTPase Drp1 participates in mitochondrial fission. J Biol Chem 2007;282:11521-9.

77. Kashatus DF, Lim K-H, Brady DC, Pershing NL, Cox AD, Counter CM. RALA and RALBP1 regulate mitochondrial fission at mitosis. Nat Cell Biol 2011;13:1108-15.

78. Díaz-Martínez LA, Karamysheva ZN, Warrington R, Li B, Wei S, Xie XJ, Roth MG, Yu H. Genome-wide siRNA screen reveals coupling between mitotic apoptosis and adaptation. EMBO J 2014;33:1960-76.

79. Park YY, Ahn JH, Cho MG, Lee JH. ATP depletion during mitotic arrest induces mitotic slippage and APC/CCdh1-dependent cyclin B1 degradation. Exp Mol Med 2018;50:46.

80. Diaz-Martinez LA, Yu H. The complexity of life and death decisions in mitosis. Mol Cell Oncol 2015;2:e969658.

81. Horn SR, Thomenius MJ, Johnson ES, Freel CD, Wu JQ, Coloff JL, Yang CS, Tang W, An J, Ilkayeva OR, Rathmell JC, Newgard CB, Kornbluth S. Regulation of mitochondrial morphology by APC/CCdh1-mediated control of Drp1 stability. Mol Biol Cell 2011;22:1207-16.

82. Wang C, Li Z, Lu Y, Du R, Katiyar S, Yang J, Fu M, Leader JE, Quong A, Novikoff PM, Pestell RG. Cyclin D1 repression of nuclear respiratory factor 1 integrates nuclear DNA synthesis and mitochondrial function. Proc Natl Acad Sci U S A 2006;103:11567-72.

83. Lee Y, Dominy JE, Choi YJ, Jurczak M, Tolliday N, Camporez JP, Chim H, Lim JH, Ruan HB, Yang X, Vazquez F, Sicinski P, Shulman GI, Puigserver P. Cyclin D1-Cdk4 controls glucose metabolism independently of cell cycle progression. Nature 2014;510:547-51.

84. Wang Z, Fan M, Candas D, Zhang TQ, Qin L, Eldridge A, Wachsmann-Hogiu S, Ahmed KM, Chromy BA, Nantajit D, Duru N, He F, Chen M, Finkel T, Weinstein LS, Li JJ. Cyclin B1/Cdk1 coordinates mitochondrial respiration for cell-Cycle G2/M progression. Dev Cell 2014;29:217-32.

85. Choi E, Zhang X, Xing C, Yu H. Mitotic checkpoint regulators control insulin signaling and metabolic homeostasis. Cell 2016;166:567-81.

86. Zhang X, Ling Y, Guo Y, Bai Y, Shi X, Gong F, Tan P, Zhang Y, Wei C, He X, Ramirez A, Liu X, Cao C, Zhong H, Xu Q, Ma RZ. Mps1 kinase regulates tumor cell viability via its novel role in mitochondria. Cell Death Dis 2016;7:e2292.

87. Dohi T, Beltrami E, Wall NR, Plescia J, Altieri DC. Mitochondrial survivin inhibits apoptosis and promotes tumorigenesis. J Clin Invest 2004;114:1117-27.

88. Gemin A, Sweet S, Preston TJ, Singh G. Regulation of the cell cycle in response to inhibition of mitochondrial generated energy. Biochem Biophys Res Commun 2005;332:1122-32.

89. Schieke SM, McCoy JP Jr, Finkel T. Coordination of mitochondrial bioenergetics with G 1 phase cell cycle progression. Cell Cycle 2008; 7:1782-7.

90. Qian W, Choi S, Gibson GA, Watkins SC, Bakkenist CJ, Van Houten B. Mitochondrial hyperfusion induced by loss of the fission protein Drp1 causes ATM-dependent G2/M arrest and aneuploidy through DNA replication stress. J Cell Sci 2012;125:5745.

91. Marsboom G, Toth PT, Ryan JJ, Hong Z, Wu X, Fang YH, Thenappan T, Piao L, Zhang HJ, Pogoriler J, Chen Y, Morrow E, Weir EK, Rehman J, Archer SL. Dynamin-related protein 1-mediated mitochondrial mitotic fission permits hyperproliferation of vascular smooth muscle cells and offers a novel therapeutic target in pulmonary hypertension. Circ Res 2012;110:1484-97.

92. Westrate LM, Sayfie AD, Burgenske DM, MacKeigan JP. Persistent mitochondrial hyperfusion promotes G2/M accumulation and caspase-dependent cell death. PLoS One 2014;9:e91911.

93. Lee S, Park YY, Kim SH, Nguyen OT, Yoo YS, Chan GK, Sun X, Cho H. Human mitochondrial Fis1 links to cell cycle regulators at G2/M transition. Cell Mol Life Sci 2014;71:711-25.

94. Xie X, Dubrovsky EB. Knockout of Drosophila RNase Z-L impairs mitochondrial transcript processing, respiration and cell cycle progression. Nucleic Acids Res 2015;43:gkv1149.

95. Donthamsetty S, Brahmbhatt M, Pannu V, Rida PC, Ramarathinam S, Ogden A, Cheng A, Singh KK, Aneja R. Mitochondrial genome regulates mitotic fidelity by maintaining centrosomal homeostasis. Cell Cycle 2014;13:2056-63.

96. Tanwar DK, Parker DJ, Gupta P, Spurlock B, Alvarez RD, Basu MK, Mitra K. Crosstalk between the mitochondrial fission protein, Drp1, and the cell cycle is identified across various cancer types and can impact survival of epithelial ovarian cancer patients. Oncotarget 2016;7:60021-37.

97. Salazar-Roa M, Malumbres M. Fueling the cell division cycle. Trends Cell Biol 2017;27:69-81.

98. Kidd T, Abu-Shumays R, Katzen A, Sisson JC, Jiménez G, Pinchin S, Sullivan W, Ish-Horowicz D. The epsilon-subunit of mitochondrial ATP synthase is required for normal spindle orientation during the Drosophila embryonic divisions. Genetics 2005; 170:697-708.

99. Yamamori T, Ike S, Bo T, Sasagawa T, Sakai Y, Suzuki M, Yamamoto K, Nagane M, Yasui H, Inanami O. Inhibition of the mitochondrial fission protein dynamin-related protein 1 (Drp1) impairs mitochondrial fission and mitotic catastrophe after x-irradiation. Mol Biol Cell 2015; 26: 4607-17.

100. Liu L, Trimarchi JR, Smith PJS, Keefe DL. Mitochondrial dysfunction leads to telomere attrition and genomic instability. Aging Cell 2002;1:40-6. 
101. Veatch JR, McMurray MA, Nelson ZW, Gottschling DE. Mitochondrial dysfunction leads to nuclear genome instability via an ironsulfur cluster defect. Cell 2009;137:1247-58.

102. Choudhury AR, Tiwari HK. Numtogenesis as a mechanism for development of cancer. Semin Cancer Biol 2017;47:101-9.

103. Chen D, Xue W, Xiang J. The intra-nucleus integration of mitochondrial DNA (mtDNA) in cervical mucosa cells and its relation with c-myc expression. J Exp Clin Cancer Res 2008;27:36.

104. Srinivasainagendra V, Sandel MW, Singh B, Sundaresan A, Mooga VP, Bajpai P, Tiwari HK, Singh KK. Migration of mitochondrial DNA in the nuclear genome of colorectal adenocarcinoma. Genome Med 2017;9:31.

105. Shay JW, Werbin H. New evidence for the insertion of mitochondrial DNA into the human genome: significance for cancer and aging. Mutat Res 1992;275:227-35.

106. Ichim G, Lopez J, Ahmed SU, Muthalagu N, Giampazolias E, Delgado ME, Haller M, Riley JS, Mason SM, Athineos D, Parsons MJ, van de Kooij B, Bouchier-Hayes L, Chalmers AJ, Rooswinkel RW, Oberst A, Blyth K, Rehm M, Murphy DJ, Tait SWG. Limited mitochondrial permeabilization causes DNA damage and genomic instability in the absence of cell death. Mol Cell 2015;57:860-72.

107. Kitazumi I, Tsukahara M. Regulation of DNA fragmentation: the role of caspases and phosphorylation. FEBS J 2011;278:427-41.

108. Hangen E, Blomgren K, Bénit P, Kroemer G, Modjtahedi N. Life with or without AIF. Trends Biochem Sci 2010;35:278-87.

109. Joza N, Susin SA, Daugas E, Stanford WL, Cho SK, Li CY, Sasaki T, Elia AJ, Cheng HY, Ravagnan L, Ferri KF, Zamzami N, Wakeham A, Hakem R, Yoshida H, Kong YY, Mak TW, Zúñiga-Pflücker JC, Kroemer G, Penninger JM. Essential role of the mitochondrial apoptosis-inducing factor in programmed cell death. Nature 2001;410:549-54.

110. Shelar SB, Kaminska KK, Reddy SA, Kumar D, Tan CT, Yu VC, Lu J, Holmgren A, Hagen T, Chew EH. Thioredoxin-dependent regulation of AIF-mediated DNA damage. Free Radic Biol Med 2015;87:125-36.

111. Minocherhomji S, Tollefsbol TO, Singh KK. Mitochondrial regulation of epigenetics and its role in human diseases. Epigenetics 2012;7:326-34.

112. Castegna A, Iacobazzi V, Infantino V. The mitochondrial side of epigenetics. Physiol Genomics 2015;47:299-307.

113. Smiraglia D, Kulawiec M, Bistulfi GL, Gupta SG, Singh KK. A novel role for mitochondria in regulating epigenetic modifications in the nucleus. Cancer Biol Ther 2008;7:1182-90.

114. Bellizzi D, D’Aquila P, Giordano M, Montesanto A, Passarino G. Global DNA methylation levels are modulated by mitochondrial DNA variants. Epigenomics 2012;4:17-27.

115. Amuthan G, Biswas G, Ananadatheerthavarada HK, Vijayasarathy C, Shephard HM, Avadhani NG. Mitochondrial stress-induced calcium signaling, phenotypic changes and invasive behavior in human lung carcinoma A549 cells. Oncogene 2002;21:7839-49.

116. Guha M, Srinivasan S, Ruthel G, Kashina AK, Carstens RP, Mendoza A, Khanna C, Van Winkle T, Avadhani NG. Mitochondrial retrograde signaling induces epithelial-mesenchymal transition and generates breast cancer stem cells. Oncogene 2014;33:5238-50.

117. Hanahan D, Weinberg RA. Hallmarks of cancer: the next generation. Cell 2011;144:646-74. 